\title{
Evaluasi Perancangan Pencahayaan Pada Ruang Low stimulus dan High stimulus Untuk Mengakomodasi Kegiatan Belajar Individu Autisme Di Sekolah Mandiga, Jakarta
}

\author{
Ari Ani Mandala ${ }^{1}$, Vanessa Yudhsitantra ${ }^{2}$ \\ Universitas Katolik Parahyangan \\ Email : ariani.mandala@unpar.ac.id
}

\begin{abstract}
Abstrak- Bagi individu autisme yang memiliki kecenderungan sebagai visual learner, perancangan pencahayaan khusus diperlukan untuk mengatasi gangguan sensori dan sebagai media untuk berkomunikasi serta mengenal dunia sekitarnya. Namun informasi perancangan khusus bagi individu autisme masih terbatas karena minimnya pengetahuan dan kompleksitas kebutuhan individu autisme. Sekolah Mandiga di Jakarta merupakan sekolah dan tempat terapi khusus bagi individu dengan spektrum autistik. Penelitian ini bertujuan untuk mengeksplorasi kebutuhan pencahayaan bagi individu autisme dan mengevaluasi perancangan pencahayaan pada Sekolah Mandiga dalam mendukung kegiatan belajar individu autisme berdasarkan kategori perancangan ruang high stimulus dan low stimulus. Pengukuran data kuantitatif iluminasi dan luminansi diambil menggunakan simulasi DiaLux Evo serta data kualitatif menggunakan kuesioner persepsi pengguna ruang. Pada Sekolah Mandiga, terdapat perbedaan dalam desain ruang dan pencahayaan pada ruang-ruang dengan aktivitas stimulus rendah dan tinggi. Penggunaan warna elemen pelingkup dan pengisi ruang, jenis sumber cahaya, dan desain bukaan menentukan stimulasi visual dan menampilkan kesan ruang yang berdampak pada perilaku pengguna ruang. Perancangan cahaya berhasil memberi efek menenangkan dan fokus pada ruang-ruang kelas individu, namun kurang menarik dan kurang membangkitkan semangat pada ruang-ruang dengan aktivitas stimulus tinggi. Secara keseluruhan, kenyamanan visual ruangruang di Sekolah Mandiga dipersepsikan cukup baik karena dinilai dapat mereduksi distraksi visual, cukup terang, jelas, terasa luas, dan aman.
\end{abstract}

Kata kunci: pencahayaan, individu autisme, ruang high stimulus, ruang low stimulus, Sekolah Mandiga Jakarta

\section{PENDAHULUAN}

Individu dengan spektrum autisme memiliki gangguan interaksi sosial, gangguan komunikasi, gangguan perilaku motorik, gangguan emosi, dan gangguan sensori (Sutadi dikutip dalam Nugraheni, 2012). Oleh sebabnya, anak autisme membutuhkan bantuan untuk memahami proses komunikasi di lingkungannya, salah satunya dengan perancangan elemen ruang yang sesuai. Perancangan sangat berperan dalam kegiatan belajar individu autisme dan mempengaruhi bagaimana individu autisme bekerja dan menerima pengalaman ruang (Yates, 2016).
Namun sayangnya arsitektur yang ada saat ini di Indonesia masih minim. Rancangan yang ada dibuat berdasarkan kebutuhan dari manusia normal pada umumnya. Masih kurangnya kesadaran akan perancangan khusus untuk individu kebutuhan khusus seperti individu autisme. Sebaliknya, perancangan ruang yang spesifik dapat membantu individu autisme merasa nyaman dan berkomunikasi dengan lebih baik sehingga dapat mempercepat proses penyembuhan. Hal ini terkait dengan kebutuhan ruang individu autisme yang khusus. Akibat indera yang hipersensitif, ruang yang sesuai untuk individu autisme harus 
Fakultas Seni Rupa dan Desain - Universitas Tarumanagara

Ari Ani Mandala, Vanessa Yudhsitantra; Halaman 25-39

mementingkan kebisingan suara, pencahayaan, warna, dan penggunaan tekstur. Warna dan tekstur tertentu atau cahaya yang terlalu kontras, terlalu bising, terlalu gelap dapat menciptakan 'tantrum' pada individu autisme (Ginanjar, 2007).

Cahaya berperan penting dalam menciptakaan emosi pada suatu ruang, khususnya bagi individu dengan spektrum austistik yang lebih mudah berkomunikasi secara visual. Ruang dengan cahaya yang baik menimbulkan perasaan aman dan nyaman bagi individu autisme serta menciptakan emosi yang kondusif untuk berkomunikasi sehingga dapat belajar dengan baik. Seringkali individu dengan autisme memiliki sensitivitas tinggi terhadap cahaya yang terlalu kontras atau silau. Khususnya untuk individu autisme hipersensori yang sangat peka terhadap cahaya, cahaya langsung dapat menciptakan silau yang dapat menciptakan frustasi gelisah, pusing, dan sakit mata (Mustofa, 2008). Mengurangi rangsangan yang menganggu adalah prioritas pertama pada ruang sekolah dengan spektrum autistik. Gangguan tersebut dapat diminalisir dengan desain yang baik dari tata letak fisik ruang, finishing ruang, dan desain pencahayaan yang baik (Long, 2010). Melihat pentingnya hal tersebut, penelitian ingin mengkaji lebih lanjut perancangan pencahayaan ruang kelas berdasarkan kebutuhan individu autisme pada ruang ramah autisme seperti sekolah autisme.

Sekolah Mandiri dan Bahagia atau yang juga dikenal dengan Sekolah Mandiga merupakan sekolah dan tempat terapi khusus bagi individu dengan spektrum autistik. Sekolah Mandiga memberi pelatihan yang bertujuan untuk mendorong kemandirian individu dengan spektrum autistik dalam kemandirian berbagai aspek dari umur 7 hingga 20 tahun. Bangunan dengan dua lantai ini tidak hanya menampung kegiatan belajar mengajar, tetapi juga dilengkapi dengan ruang-ruang praktek kegiatan sehari-hari seperti taman, dapur, dan ruang tidur.

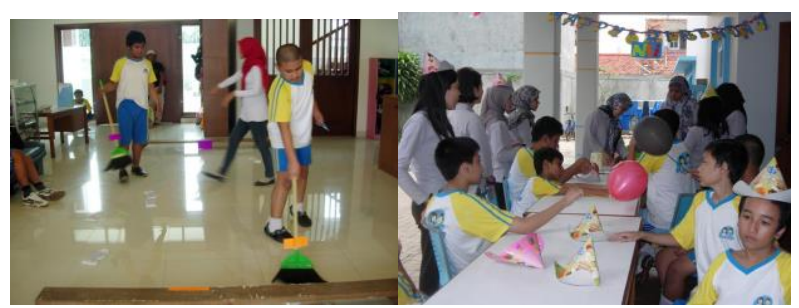

Gambar 1. Kegiatan pada Sekolah Mandiga. (Sumber: http://coderhutan.com/mandiga/profil-sejarah/)

Salah satu karakteristik perancangan ruang untuk individu dengan spektrum autistik adalah memisahkan area tidak berdasarkan privasi, namun berdasarkan stimulasi visual tinggi dan rendah. Ruang high stimulus merupakan ruang dengan tujuan untuk menciptakan kewaspadaan tinggi dengan tingkat stimulasi tinggi (high load), sedangkan ruang low stimulus merupakan ruang dengan 
stimulasi rendah (low load) dengan tujuan untuk meningkatkan konsentrasi (Mustofa, 2014). Penelitian ini bertujuan untuk mengeksplorasi kebutuhan pencahayaan bagi individu autisme dan mengevaluasi apakah perancangan pencahayaan yang digunakan pada Sekolah Mandiga sudah mendukung kegiatan belajar individu autisme pada ruangruang berdasarkan kategori perancangan ruang dengan stimulasi visual tinggi dan rendah. Perancangan ruang dan cahaya yang digunakan dinilai performanya melalui pengukuran data kuantitatif dan persepsi pengguna ruang. Penelitian ini bermanfaat untuk meningkatkan ilmu pengetahuan mengenai kebutuhan bagi individu autisme dilihat dari strategi pencahayaan ruang yang digunakan. Diharapkan dengan adanya penelitian ini dapat meningkatkan kesadaran akan ilmu rancang bangun terutama pada kenyamanan visual akibat pencahayaan yang sesuai dengan kebutuhan penggunanya, khususnya bagi pengguna yang memiliki kebutuhan spesifik seperti autisme.

\section{METODE}

Metode yang digunakan untuk mengeksplorasi kebutuhan pencahayaan bagi individu autisme adalah dengan mengkaji studi literatur. Sedangkan penjajakan (studi kelayakan) perancangan pencahayaan Sekolah Mandalika terhadap referensi cahaya ruang belajar individu autisme dilakukan secara deskriptifevaluatif dengan pengambilan data kuantitatif dan kualitatif. Ruang pada Sekolah Mandiga di observasi dengan mengidentifikasi elemen arsitektural pelingkup ruang (material, warna, tekstur) maupun teknik pencahayaan yang digunakan (baik pencahayaan alami maupun pencahayaan buatan). Nilai transmisi kaca (bukaan) diukur menggunakan transmittance meter. Selain itu juga diambil daya kontras warna dari elemen pelingkup dan perabot ruang sebagai salah satu variabel untuk menganalisis tingkat stimulasi visual. Kontras warna diambil dengan menggunakan foto ruang yang dianalisis pada aplikasi Image Color Summarizer untuk mendeskripsikan warna yang digunakan serta presentasenya. Kontras warna dianalisis secara kualitatif berdasarkan kedekatan 1 warna dengan yang lainnya dan pengaruh penggunaan warna terhadap emosi dan psikologis manusia.

Pengukuran data kuantitatif dilakukan dengan pengukuran instrumen pada objek studi menggunakan luxmeter dan simulasi dengan perangkat lunak DiaLux Evo untuk mendapatkan data iluminasi, kemerataan cahaya, dan luminansi dalam ruang. Simulasi dilakukan pada pukul 08.00, 12.00, dan 16.00 yang mewakili waktu aktivitas pagi, siang, dan sore hari di Sekolah Mandiga. Pengukuran data 
di lapangan dilakukan untuk memvalidasi nilai iluminasi dari simulasi perangkat lunak. Pengukuran di lapangan dilakukan pada pukul 10.00 WIB, yaitu pada jam istirahat agar tidak mengganggu kegiatan belajar mengajar sekolah. Bidang kerja ditentukan pada ketinggian $75 \mathrm{~cm}$. Titik pengukuran pada tiap ruang dibagi menjadi dua berdasarkan pencahayaan yang dibutuhkan ruang yaitu pencahayaan umum ruang (general lighting) dan pencahayaan kegiatan (task lighting). Untuk ruang dengan tugas visual titik ukur diletakan pada meja kerja (ruang belajar) individu autisme dalam ruang kelas tersebut, sedangkan untuk pencahayaan umum ruang dibagi menjadi beberapa titik sesuai dengan luasnya mengikuti referensi dari SNI 16-70622004 mengenai tata cara pengukuran intensitas penerangan di tempat kerja.

Data kualitatif dari persepsi pengguna ruang dilakukan melalui pengisian kuesioner. Adanya keterbatasan komunikasi individu autisme khususnya pada orang yang baru dikenal dan keterbatasan dalam mendapatkan ijin, maka kuesioner diisi oleh seluruh tenaga pengajar di Sekolah Mandiga (9 orang) untuk mendapatkan data penilaian kondisi dan suasana ruang serta perilaku murid di Sekolah Mandiga. Kuisioner dibagi menjadi 2 bagian, memberi penilaian terhadap penyataan terkait Sekolah Mandiga dan memberi penilaian terhadap kata yang memiliki asosiasi dengan perancangan cahaya ruang untuk autisme. Kuesioner pertama dibagi menjadi 2 kelompok pernyataan, berupa pernyataan-pernyataan terkait aspek perancangan sekolah Mandiga pada ruang stimulasi tinggi dan rendah. Kelompok pernyataan ini diperoleh dari kajian literatur mengenai perancangan cahaya bagi individu autisme. Pertanyaan menggunakan skala Likert 5 poin dari sangat tidak setuju (STS) sampai dengan sangat setuju (SS).

Pada bagian kedua, merupakan data persepsi suasana ruang dan emosi pengguna berisi kata-kata yang diasosiasikan dengan kebutuhan perancangan pencahayaan sekolah autisme yang ingin dicapai. Kata-kata yang digunakan mengadopsi dari metode Russel (1980) dan Vogels (2008) yang juga digunakan oleh Mandala \& Sheila (2018) untuk mengukur atmosfer ruang dan dampaknya terhadap mood pengguna. Pengisian kuesioner dilakukan dengan 5 skala semantik diferensial. Untuk ruang dengan stimulasi tinggi digunakan asosiasi kata meliputi persepsi sempit-luas; mencekam-aman; kabur-jelas; gelap-terang; kontras-seragam; variatif-monoton; sederhana-kompleks; membosankanmenyenangkan; tegang-santai; dan suramceria untuk ruang dengan stimulasi tinggi. Untuk menilai persepsi suasana ruang dengan stimulasi rendah digunakan padanan kata-kata 
Fakultas Seni Rupa dan Desain - Universitas Tarumanagara

Ari Ani Mandala, Vanessa Yudhsitantra; Halaman 25-39

meliputi: sempit-luas; mencekam-aman; kabur-jelas; gelap-terang; kontras-seragam; monoton-variatif; kompkes-sederhana; mengecewakan-memuaskan; meresahkanmenenangkan; dan terganggu-fokus. Kata-kata tersebut berelasi dengan aspek-aspek perancangan sekolah pada kuesioner bagian pertama.

Analisis dilakukan dengan mengevaluasi kesesuaian kondisi pencahayaan di Sekolah Mandiga (data observasi ruang dan elemen pelingkup ruang, simulasi pencahayaan, dan hasil kuesioner persepsi pengguna ruang) dengan rekomendasi perancangan pencahayaan berdasarkan studi literatur. Pembahasan dibagi menjadi 2 kategori ruang berdasarkan tingkat stimulasi visual, yaitu ruang dengan stimulasi rendah dan tinggi.

\section{HASIL DAN PEMBAHASAN}

Sekolah Mandiga terletak di Jalan Cipete, Jakarta Selatan. Bangunan Sekolah Mandiga terdiri dari 2 lantai dan berada pada tapak yang berhubungan langsung dengan area komersial dan jalan raya yang cukup padat. Di sekeliling tapak perancangan terdapat tembok setinggi 3 $m$ dan pepohonan yang membatasi tapak Sekolah Mandiga dengan area sekitarnya. Sehingga pada penelitian ini pengaruh dari bangunan sekitar tidak diperhitungkan pada analisa. Bangunan berada di tengah tapak berbentuk persegi panjang yang cukup tebal dengan orientasi ke arah Utara. Karena bentuknya yang tebal, terdapat beberapa ruangan yang tidak mendapatkan cahaya alami langsung dan mengandalkan sumber cahaya buatan sepanjang hari. Ruang terbuka pada tapak bagian belakang cukup luas untuk beraktivitas seperti olahraga, beternak lele, maupun kegiatan aktivitas di ruang luar lainnya. Dari tampilan fasad bangunan, didominasi komposisi bukaan jendela (dengan kanopi) dan dinding masif berwarna netral. Terdapat aksentuasi berupa warna kuning dan biru yang merepresentasikan warna Sekolah Mandiga.

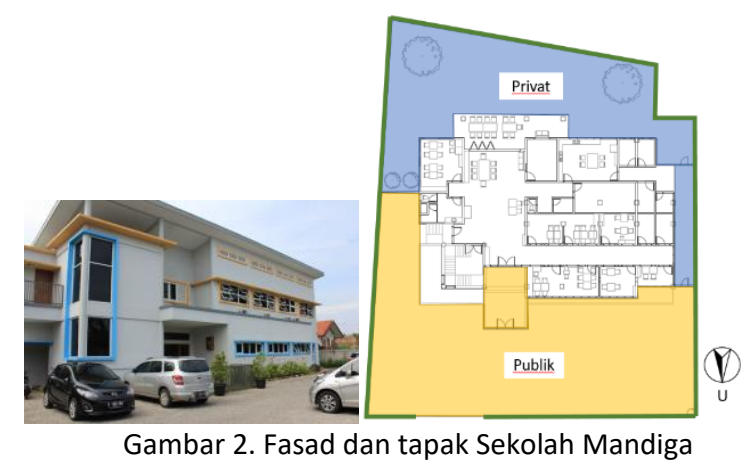

Akibat keterbatasan lahan, ruang kelas, dan jumlah staf pengajar yang ada di Sekolah Mandiga tidak sebanding dengan perkembangan jumlah murid, maka sekolah dibagi menjadi 2 sesi yaitu pagi (08.15-12.00) dan siang (13.00-16.00) dengan total 25 murid. Seluruh ruang belajar individu autisme di Sekolah Mandiga di kategorikan berdasarkan stimulasi visual yang diperlukan yaitu low stimulus dan high stimulus. Pada Sekolah 
Fakultas Seni Rupa dan Desain - Universitas Tarumanagara

Ari Ani Mandala, Vanessa Yudhsitantra; Halaman 25-39

Mandiga, ruang yang dapat digolongkan sebagai ruang low stimulus merupakan ruang seklusi dan ruang kelas formal, sedangkan ruang high stimulus terdiri dari ruang praktek keseharian, ruang musik, ruang praktek dapur, toilet, dan ruang penerima seperti lobi. Pembahasan mengenai perancangan ruang dan pencahayaan dilakukan dengan membagi ruang-ruang berdasarkan kategori stimulasi visual tinggi dan rendah tersebut. Ruang-ruang lainnya di lantai 2 tidak menjadi bagian dalam penelitian seperti ruang serba guna dan ruang untuk staff pengajar seperti ruang kantor, ruang rapat, toilet karyawan, dan pantri. Sedangkan ruang makan/istirahat pada lantai 1 juga tidak dikaji dalam penelitian karena ruang bersifat terbuka.

Bagi invidu autis, pola yang menciptakan ruang sosialisasi menjadi penting disebabkan keterbatasan kemampuan interaksi sosialnya. Oleh karenanya ruang yang di tata secara radial adalah paling direkomendasikan, dimana ruang-ruang kelas saling berhadapan yang dipisahkan oleh koridor yang akan menciptakan ruang interaksi sosial dan berpusat pada satu titik yang menjadi ruang berkumpul dan bersosialisasi (Septia dkk, 2017). Pada Sekolah Mandiga, ruang lobi dan ruang makan bersama menjadi pusat interaksi sosial dengan ruang-ruang kelas individu berderet dan berhadapan (dipisahkan oleh koridor) pada sisi Timur serta ruang kelas gabungan pada sisi Barat.

Tabel 1 Ruang Sekolah Mandiga

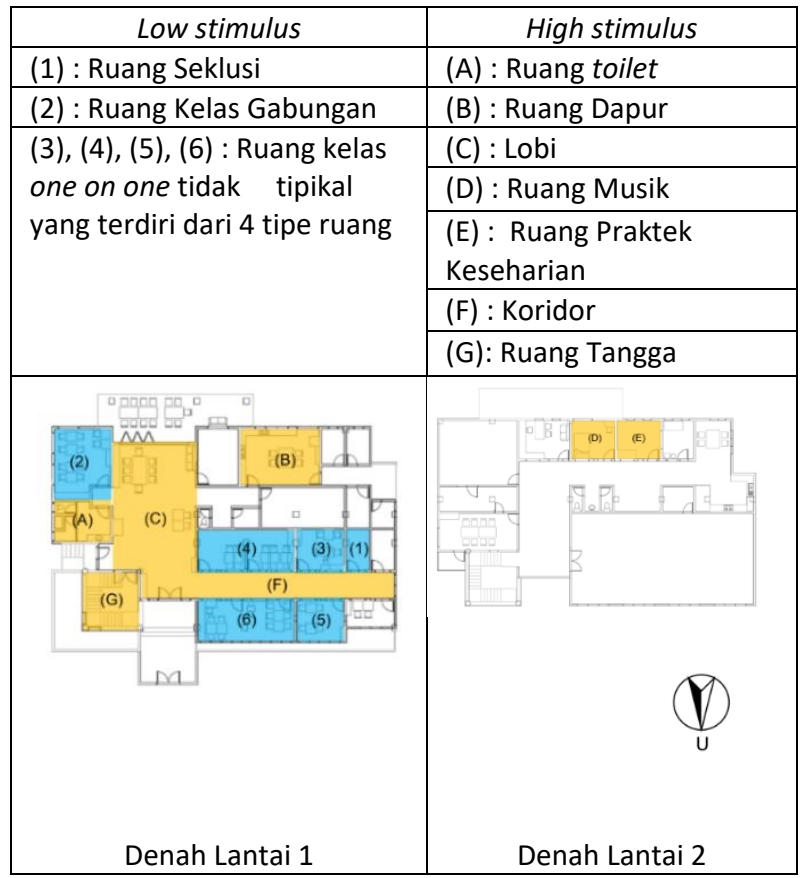

\section{Evaluasi ruang-ruang dengan stimulasi visual rendah (low stimulus)}

Tabel 2. Ruang-ruang dengan karakteristik stimulasi visual rendah dan karakteristik warna ruangnya

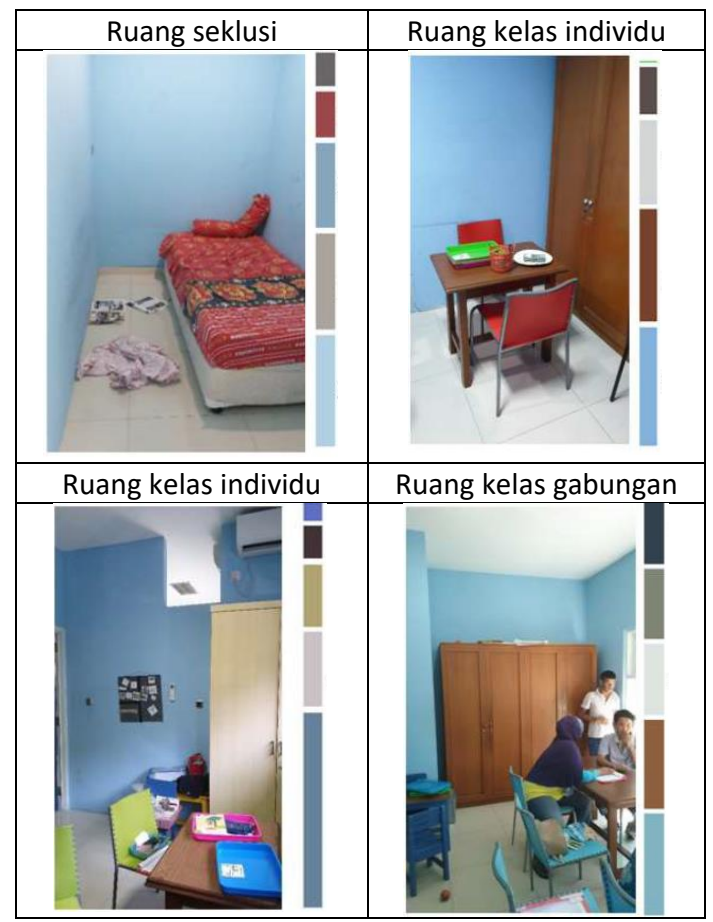


Rancangan ruang untuk area stimulasi rendah adalah menciptakan suasana menenangkan, terutama pada ruang seklusi. Ruang tenang / ruang seklusi merupakan ruang untuk individu spektrum autistik yang mengalami overstimulation selama melakukan kegiatan belajar istirahat sejenak dan menenangkan dirinya (Ginanjar, 2007). Tenang yang dimaksud pada ruang ini merupakan ruang yang memberi perasaan santai untuk membantu individu autisme menenangkan diri dari stimulasi yang berlebihan. Ruang tenang tersebut berfungsi untuk menetralkan sensori dan meminimalkan stimulasi sehingga kegiatan belajar yang akan dilakukan menjadi lebih positif ketika individu dengan austisme sedang mengalami tantrum. Penggunaan cahaya yang tidak seragam, tingkat iluminasi lebih rendah, dan warna sumber cahaya hangat dapat membantu menciptakan suasana ruang yang menenangkan (Egan, 2002). Selain itu ruang low stimulus seperti ruang kelas sebagai ruang yang membutuhkan konsentrasi tinggi juga memerlukan kontras pada elemen pengisi ruang sehingga individu autisme tertarik pada aktivitas yang dilakukan (Manchala, 2014).

Ruang-ruang stimulasi rendah di Sekolah Mandiga menggunakan tipe bukaan bervariasi. Pada beberapa ruang terdapat keterbatasan membuka jendela sehingga penerangan menggunakan cahaya buatan yang menempel pada plafon dengan temperatur warna cahaya putih-kebiruan. Tidak terdapat variasi pada sumber cahaya buatan, sistem penerangan yang digunakan bersifat umum menggunakan variasi lampu fluorescent ( $T L$ dan $C F L)$. Temperatur warna cahaya lampu yang tinggi kurang cocok untuk ruang seklusi yang memerlukan suasana tenang dan rileks, namun baik untuk aktivitas belajar di ruang kelas. Penggunaan lampu tipe fluorescent yang memiliki karakteristik cahaya difus juga baik untuk mengurangi resiko silau. Ruang seklusi hanya memiliki bukaan kecil untuk meminimalkan distraksi, sedangkan ruang kelas memiliki bukaan lebih besar yang bervariasi. Beberapa bukaan memiliki kontrol cahaya dengan menggunakan kaca film untuk mengurangi transmisi, dan beberapa bukaan lebih transparan menampilkan pemandangan natural berupa pepohonan di sekeliling tapak sekolah. Bukaan dengan pemandangan pada ruang kelas memberikan koneksi yang nyaman ke lingkungan luar (Long, 2010). Pada bukaan tertentu yang menghadap ke koridor berpotensi menggangu individu autisme karena terdapat aktivitas orang berlalu-lalang, sehingga kaca yang digunakan dengan nilai tranmisi rendah dan warna gelap untuk mencegah distraksi visual bagi individu autisme. Sebagian besar posisi bukaan merupakan tipe bukaan samping di bagian atas yang dapat menciptakan distribusi cahaya 
Fakultas Seni Rupa dan Desain - Universitas Tarumanagara

Ari Ani Mandala, Vanessa Yudhsitantra; Halaman 25-39

lebih merata de dalam ruang (Lechner, 2015).

Posisi bukaan yang tinggi juga menyebabkan cahaya terdifusi sehingga tidak langsung mengenai pandangan mata pengamat (Long, 2010).

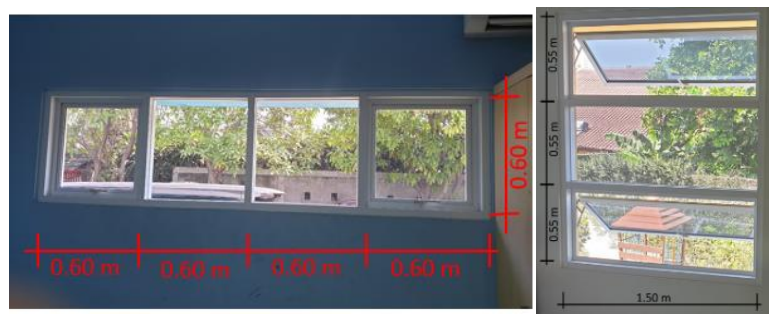

Gambar 3. Bukaan ruang kelas yang mendapatkan pemandangan keluar tapak

Iluminasi terlalu tinggi dapat menyebabkan kecemasan dan frustasi bagi anak dengan spektrum autisme, oleh karenanya direkomendasikan tingkat cahaya yang lebih rendah dari standar umumnya berkisar 250350 lux (Long, 2010). Pengukuran tingkat iluminasi di ruang kelas Sekolah Mandiga memperlihatkan variasi nilai iluminasi berbeda pada ruang-ruang dengan bukaan jendela yang memiliki akses penetrasi cahaya alami langsung dari luar (tapak) yaitu rata-rata mencapai 100-200 lux atau lebih dan tidak memiliki bukaan langsung ke luar (rata-rata $<100$ lux). Variasi nilai iluminasi juga dipengaruhi posisi pengukuran (area aktivitas), desain bukaan (jumlah, posisi, material, dan rasio bukaan), dan sistem penerangan buatan (jenis, posisi, jumlah lampu). Meskipun tingkat iluminasi ini belum memenuhi rekomendasi, namun ruang tetap dipersepsikan cukup terang menurut hasil kuesioner. Dari distribusi cahaya. ruang kelas gabungan memiliki nilai kemerataan cahaya paling kecil $(<0.1)$ karena dimensi bukaan yang besar, sedangkan ruang seklusi memiliki kemerataan cahaya paling baik (0.76) karena hanya memiliki bukaan kecil (menghadap ke koridor bangunan) sehingga penerangan didapat merata dari sumber pencahayaan buatan. Ruang kelas individu memiliki nilai kemerataan cahaya bervariasi (0.2-0.5) yang dipengaruhi dari variasi jenis sumber cahaya dan desain bukaan. Kemerataan cahaya diperlukan untuk menghindari rasio terang yang berlebihan dan terjadinya area bayangan gelap pada ruang (Long, 2010).

Berdasarkan 'Architectural Energy Corporation' (dikutip dalam Gunawan, 2019) rasio luminasi dari luminasi cahaya tertinggi dan terendah suatu ruang ( $\operatorname{Lmax} / \mathrm{Lmin}$ ) dalam bidang pandang mata yang melebihi rasio 10:1 dapat menyebabkan penurunan efisiensi visual sedangkan rasio luminasi yang lebih tinggi dari 20:1 dapat menyebabkan silau (glare). Anak dengan spektrum autisme memiliki sensitifitas lebih tinggi terhadap cahaya, sehingga direkomendasikan rasio kontras yang tidak melebihi 1:5 untuk permukaan vertikal (Long, 2010). Pengukuran rasio luminansi cahaya memperlihatkan adanya potensi silau pada 
ruang kelas gabungan dan salah satu ruang kelas yang mendapatkan cahaya alami langsung, dimana nilai rasio lebih dari 1:20 pada titik pengamat yang berada dekat dengan jendela. Pada ruang-ruang lainnya indikasi silau tidak ditemukan karena tidak ada bukaan ke luar maupun posisi pengamat yang tidak menghadap bukaan. Silau akibat sumber cahaya buatan juga tidak ditemukan karena penggunaan armatur lampu recessed ke dalam plafon dan penggunaan elemen diffuser pada lampu TL.

Tabel 3. Grafik dan titik pengukuran iluminasi ruang kelas gabungan

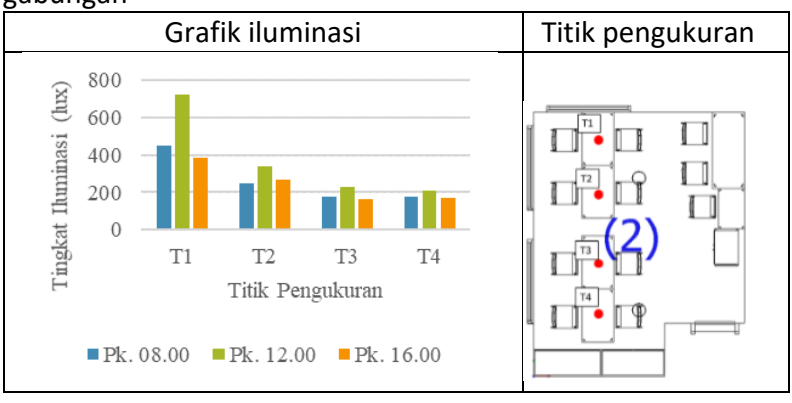

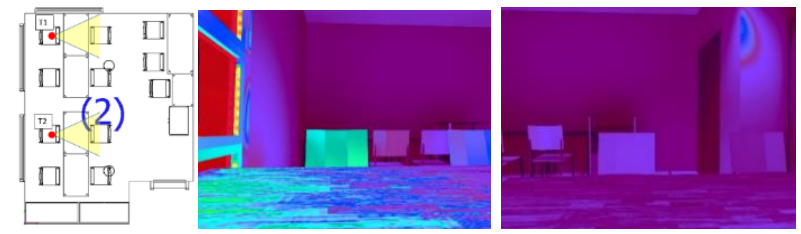

Gambar 4. Visualisasi nilai luminansi pada ruang kelas gabungan

Penggunaan warna didominasi cat berwarna biru pada dinding dan warna-warna netral cokelat untuk perabot ruang (lemari dan meja). Warna yang bersifat netral atau muted color merupakan warna yang paling sesuai untuk ruang kelas bagi individu autisme.
Muted color merupakan warna yang lembut, menenangkan, tidak terang dan kuat serta memiliki saturasi rendah sehingga dapat mengurangi stimulasi ruang (Janviere, 2009; Long, 2010). Warna biru termasuk warna dingin yang memiliki kecenderungan untuk memberi pengaruh positif seperti menyejukan dan menekan pengaruh interaksi antar manusia. Warna dingin dapat digunakan untuk meredam emosi atau amarah seseorang (Sorcar dikutip oleh Sutanto, 2017). Adanya pemandangan dari bukaan jendela, kontrol cahaya, dan warna ruang memberi kesan ruang yang teduh, menenangkan, dan nyaman bagi pengguna di dalamnya. Meskipun demikian, pemandangan visual dari bukaan dapat berpotensi menyebabkan distraksi terutama pada ruang yang membutuhkan konsentrasi seperti ruang kelas. Warna cerah digunakan terbatas pada furnitur kursi pada ruang kelas (biru / hijau / merah terang) untuk menghasilkan kontras agar terlihat lebih menarik bagi murid untuk melakukan aktivitas di dalam ruangan.

Data dari kuesioner yang berisi pernyataan mengenai kesan ruang, persepsi suasana ruang dan dampaknya terhadap individu autisme yang diisi oleh seluruh staff pengajar memperlihatkan hasil cenderung positif. Responden setuju dengan pernyataan suasana pada ruang-ruang low stimulus menenangkan 
Fakultas Seni Rupa dan Desain - Universitas Tarumanagara

Ari Ani Mandala, Vanessa Yudhsitantra; Halaman 25-39

terutama pada ruang seklusi. Kondisi tantrum masih terindikasi sering terjadi, dari jawaban responden yang cenderung netral pada pernyataan berkaitan dengan hal tersebut, namun responden setuju penggunaan warna dan penataan ruang yang sederhana memberi dampak menenangkan bagi anak autisme. Adanya kecenderungan jawaban netral pada pernyataan ketertarikan dan semangat dari anak autisme pada kegiatan belajar mengajar. Hal ini bisa jadi disebabkan penataan ruang dan cahaya yang cenderung monoton, seragam, dan sederhana dapat mengakibatkan kebosanan, terutama pada ruang-ruang tanpa bukaan jendela langsung keluar. Secara keseluruhan kenyamanan visual dirasakan cukup oleh responden karena ruang memiliki kesan terang, jelas, terasa luas dan aman.

Tabel 4. Hasil kuesioner kesesuaian perancangan ruang low stimulus di Sekolah Mandiga

\begin{tabular}{|c|c|c|c|c|c|}
\hline \multicolumn{6}{|c|}{$\begin{array}{l}\text { Ruang dengan high stimulus seperti ruang lobi, ruang } \\
\text { makan, ruang musik, dapur, ruang praktek keseharian } \\
\text { tempat tidur, dan toilet }\end{array}$} \\
\hline & STS & TS & $\mathrm{N}$ & $S$ & SS \\
\hline & -2 & -1 & 0 & 1 & 2 \\
\hline $\begin{array}{l}\text { Ruang belajar Sekolah } \\
\text { Mandiga membuat anak } \\
\text { autisme bersemangat } \\
\text { dalam melakukan kegiatan } \\
\text { belajar }\end{array}$ & - & - & 4 & 5 & - \\
\hline $\begin{array}{l}\text { Ruang kelas Sekolah } \\
\text { Mandiga dapat menarik } \\
\text { perhatian anak autisme }\end{array}$ & - & - & 4 & 5 & - \\
\hline $\begin{array}{l}\text { Ruang kelas Sekolah } \\
\text { Mandiga memiliki penataan } \\
\text { ruang yang ramai dan } \\
\text { variatif sehingga menarik } \\
\text { bagi anak autisme }\end{array}$ & - & 5 & 3 & 3 & - \\
\hline $\begin{array}{l}\text { Ruang kelas Sekolah } \\
\text { Mandiga menggunakan }\end{array}$ & - & 8 & 1 & - & - \\
\hline
\end{tabular}

\begin{tabular}{|c|c|c|c|c|c|}
\hline $\begin{array}{l}\text { warna yang ramai dan } \\
\text { variatif pada dinding, lantai, } \\
\text { atau furniture sehingga } \\
\text { menarik bagi anak autisme }\end{array}$ & & & & & \\
\hline $\begin{array}{l}\text { Anak autisme Sekolah } \\
\text { Mandiga tidak merasa } \\
\text { bosan berada pada ruang } \\
\text { Sekolah Mandiga }\end{array}$ & - & 2 & 3 & 4 & - \\
\hline
\end{tabular}

Tabel 5. Hasil pengukuran persepsi suasana ruang low stimulus

\begin{tabular}{|c|c|c|c|c|c|c|}
\hline & -2 & -1 & 0 & 1 & 2 & \\
\hline Sempit & & & & & & Luas \\
\hline Mencekam & & & & & & Aman \\
\hline Kabur & & & & & & Jelas \\
\hline Gelap & & & & & & Terang \\
\hline Kontras & & & & & & Seragam \\
\hline Variatif & & & & & & Monoton \\
\hline Kompleks & & & & & & Sederhana \\
\hline Mengecewakan & & & & & & Memuaskan \\
\hline Meresahkan & & & & & & Menenangkan \\
\hline Terganggu & & & & & & Fokus \\
\hline
\end{tabular}

\section{Evaluasi ruang-ruang dengan stimulasi visual tinggi}

Tabel 6. Ruang-ruang dengan karakteristik stimulasi visual tinggi dan karakteristik warna ruangnya

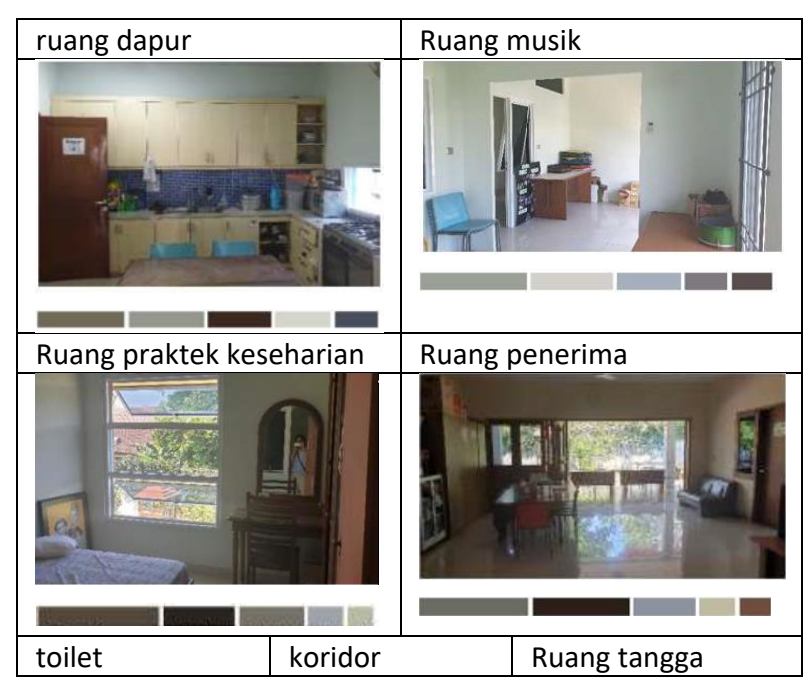




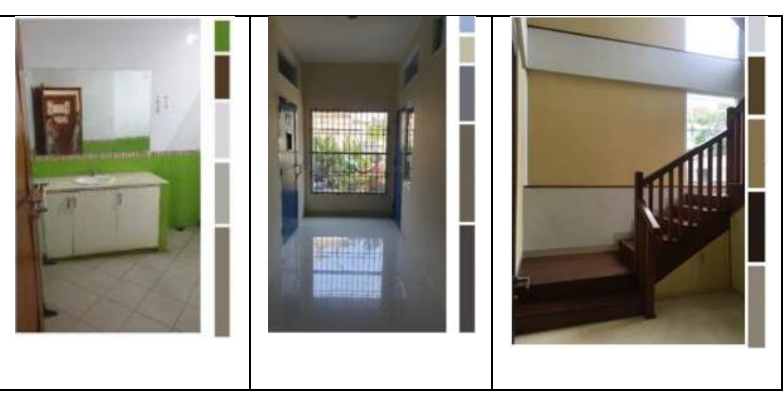

Pada rancangan ruang dengan aktivitas stimulasi tinggi digunakan tindakan preventif untuk menghadapi tantrum dari individu autisme seperti penggunaan pagar dan penggunaan jendela dengan kisi-kisi pada lorong kelas. Desain bukaan pada ruang-ruang stimulasi tinggi relatif lebih besar dibandingkan ruang-ruang stimulasi rendah. Ruang yang terang dapat mendukung reaksi non-visual berupa kewaspadaan / alertness bagi pengguna ruang (Ru et al., 2019; Smolders \& de Kort, 2014). Pada ruang dengan high stimulus digunakan tingkat kecerahan kontras yang lebih tinggi yang terbentuk dengan menggunakan sumber cahaya yang variatif, gradasi cahaya dengan intensitas yang berbeda, atau menggunakan bukaan dengan view. Kontras tersebut akan meningkatkan stimuli visual dan perasaan yang ingin dimunculkan sehingga ruang tersebut dapat memberi semangat bagi individu autisme.

Pada Sekolah Mandiga, ruang-ruang stimulus tinggi memiliki dimensi bukaan lebih besar, jenis bukaan variatif, dan pada ruang tertentu digunakan kerangka besi untuk menjaga keamanan individu autisme. Kisi-kisi juga berperan untuk melembutkan cahaya yang masuk dan mereduksi silau sehingga lebih nyaman bagi individu autisme. Nilai iluminasi ruang-ruang tersebut bervariasi dan dipengaruhi oleh desain bukaan dan sistem penerangannya. Titik ukur diambil di tengah ruangan karena aktivitas yang dilakukan umumnya tidak spesifik pada satu area kerja. Nilai iluminasi pada area lobi dan dapur berkisar 200 lux, ruang praktek dan ruang musik 100-200 lux, area toilet sekitar 100 lux, dan area koridor $<100$ lux. Meskipun nilai iluminasi tidak terlalu tinggi, namun kesan ruang cukup terang. Ini dapat disebabkan penggunaan warna pelingkup ruang dengan reflektansi tinggi (dominasi putih dan krem) sehingga menimbulkan kesan kecerahan yang lebih tinggi. Seperti pada ruang-ruang stimulasi rendah, beberapa bukaan jendela menampilkan pemandangan natural berupa pepohonan di sekeliling tapak yang dapat memberikan efek menyenangkan.

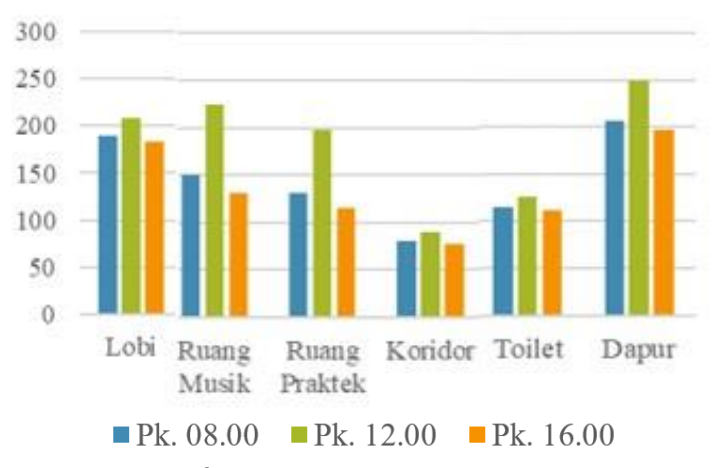

Gambar 5. Grafik iluminasi ruang-ruang stimulasi tinggi 
Fakultas Seni Rupa dan Desain - Universitas Tarumanagara

Ari Ani Mandala, Vanessa Yudhsitantra; Halaman 25-39
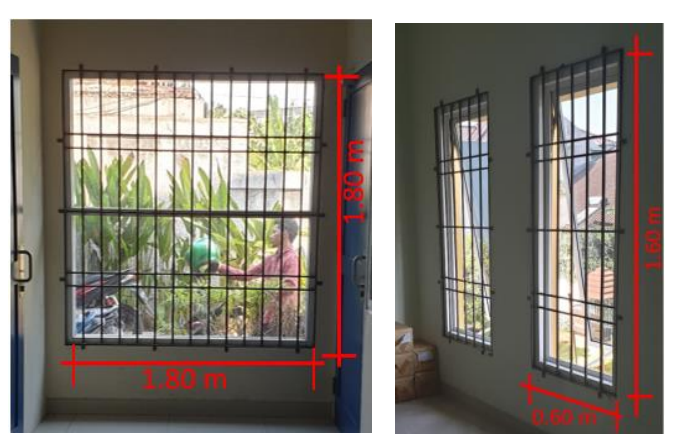

Gambar 6. Bukaan jendela dengan kisi-kisi untuk keamanan

Rekomendasi warna yang digunakan untuk membangkitkan semangat pada ruang-ruang yang membebaskan pengguna bergerak aktif adalah kombinasi warna cerah. Namun demikian, berdasarkan observasi langsung dan penguraian elemen pelingkup dan pengisi ruang, terdapat beberapa kesamaan material atau warna yang digunakan pada ruang low stimulus. Beberapa ruang high stimulus seperti ruang lobi, dapur, dan toilet menggunakan material lantai yang lebih gloss dan warna cat yang lebih cerah dari ruang low stimulus sehingga dapat menjadi potensi stimulasi bagi ruang high stimulus. Tetapi ruang kelas dengan ruang praktek keseharian seperti ruang tidur dan ruang musik tidak memiliki perbedaan material. Perbedaan kedua kelompok ruang hanya warna cat pada dinding yang keduanya dapat digolongkan sebagai muted color. Warna biru muda maupun hijau muda tersebut lebih sesuai digunakan pada ruang low stimulus, untuk menimbulkan efek tenang. Hal tersebut sesuai dengan hasil kuisioner yang dirasakan oleh pengguna Sekolah Mandiga pada ruang high stimulus yang masih dirasakan kurang variatif, ceria, dan kompleks.

Tabel 7. Hasil kuesioner kesesuaian perancangan ruang high stimulus di Sekolah Mandiga

\begin{tabular}{|c|c|c|c|c|c|}
\hline \multicolumn{6}{|c|}{$\begin{array}{l}\text { Menciptakan ruang low stimulus seperti ruang kelas dan } \\
\text { ruang seklusi pada Sekolah Mandiga }\end{array}$} \\
\hline & STS & TS & $\mathrm{N}$ & $\mathrm{S}$ & SS \\
\hline & -2 & -1 & 0 & 1 & 2 \\
\hline $\begin{array}{l}\text { Anak autisme selalu tenang } \\
\text { dan fokus pada kegiatan } \\
\text { belajar yang dilakukan } \\
\text { pada ruang kelas Sekolah } \\
\text { Mandiga }\end{array}$ & - & 2 & 3 & 4 & - \\
\hline $\begin{array}{l}\text { Ruang kelas Sekolah } \\
\text { Mandiga memiliki } \\
\text { penataan ruang yang tidak } \\
\text { ramai dan sederhana bagi } \\
\text { anak autisme sehingga } \\
\text { terasa menenangkan }\end{array}$ & - & 1 & - & 8 & - \\
\hline $\begin{array}{l}\text { Ruang kelas Sekolah } \\
\text { Mandiga menggunakan } \\
\text { penataan warna yang } \\
\text { sederhana sehingga } \\
\text { menenangkan bagi anak } \\
\text { autisme }\end{array}$ & - & - & 1 & 8 & - \\
\hline $\begin{array}{l}\text { Anak autisme tertarik dan } \\
\text { bersemangat pada } \\
\text { kegiatan belajar ruang } \\
\text { kelas Sekolah Mandiga }\end{array}$ & - & - & 5 & 4 & - \\
\hline $\begin{array}{l}\text { Ruang kelas Sekolah } \\
\text { Mandiga menenangkan } \\
\text { sehingga jarang terjadi } \\
\text { tantrum pada ruang kelas } \\
\text { Sekolah Mandiga }\end{array}$ & - & - & 6 & 3 & - \\
\hline $\begin{array}{l}\text { Ruang seklusi pada Sekolah } \\
\text { Mandiga memberi } \\
\text { perasaan tenang sehingga } \\
\text { dapat mengurangi tantrum } \\
\text { pada anak autisme }\end{array}$ & - & - & 2 & 7 & - \\
\hline
\end{tabular}


Tabel 8. Hasil pengukuran persepsi suasana ruang high stimulus

\begin{tabular}{|c|c|c|c|c|c|c|}
\hline & -2 & -1 & 0 & 1 & 2 & \\
\hline Sempit & & & & & & Luas \\
\hline Mencekam & & & & & & Aman \\
\hline Kabur & & & & & & Jelas \\
\hline Gelap & & & & & & Terang \\
\hline Seragam & & & & & & Kontras \\
\hline Monoton & & & & & & Variatif \\
\hline Sederhana & & & & & & Kompleks \\
\hline Membosankan & & & & & & Menyenangkan \\
\hline Tegang & & & & & & Santai \\
\hline Suram & & & & & & Ceria \\
\hline
\end{tabular}

Hasil kuesioner secara keseluruhan terhadap persepsi suasana ruang dan dampaknya terhadap pengguna ruang masih memperlihatkan hasil positif meskipun lebih rendah daripada penilaian ruang-ruang low stimulus. Kecenderungan responden menilai penataan ruang belajar dan penggunaan warna di Sekolah Mandiga kurang variatif sehingga kurang menarik bagi anak autisme. Secara umum kenyamanan visual pada ruangruang stimulasi tinggi dirasakan cukup oleh responden karena ruang memiliki kesan terang, jelas, terasa luas dan aman.

\section{SIMPULAN}

Cahaya menjadi faktor penting dalam merancang bagi indvidu autisme karena kemampuannya dalam menerima informasi visual dan kepekaannya terhadap cahaya. Selain itu cahaya juga dapat memberi stimulus kepada sensori visual sehingga menciptakan kenyamanan visual bagi individu autisme terlebih melalui tingkat cahaya, warna, dan kontras yang berdampak terhadap kondisi psikologisnya. Pada Sekolah Mandiga, terdapat perbedaan dalam desain ruang dan pencahayaan pada ruang-ruang dengan aktivitas stimulus rendah dan tinggi. Pada ruang low stimulus penggunaan warna netral dan dingin pada elemen pelingkup ruang, desain ruang sederhana, serta pembatasan pemandangan keluar digunakan untuk menampilkan suasana menenangkan dan mencegah distraksi visual. Iluminasi cahaya dirasakan cukup terang dan minim silau (kecuali pada ruang kelas gabungan). Pada ruang-ruang dengan aktivitas stimulasi tinggi, digunakan tindakan preventif berupa pemasangan kisi-kisi pada bukaan untuk menjaga keamanan individu autisme jika sewaktu-waktu terjadi tantrum. Desain bukaan yang relatif lebih besar dan penggunaan warna pelingkup ruang yang reflektif memberikan kesan ruang lebih terang dan berpotensi meningkatkan kewaspadaan pengguna ruang. Namun demikian, desain ruang dan pencahayaan yang seragam, dan minim variasi memberi kesan ruang kurang menarik dan dinilai kurang menimbulkan semangat bagi individu autisme oleh responden yang merupakan staff pengajar sekolah. Meskipun demikian secara keseluruhan kenyamanan visual ruang-ruang 
Jurnal Visual

Fakultas Seni Rupa dan Desain - Universitas Tarumanagara

Ari Ani Mandala, Vanessa Yudhsitantra; Halaman 25-39

di Sekolah Mandiga dipersepsikan cukup baik karena dinilai terang, jelas, ruang terasa luas, dan terasa aman.

Penelitian menunjukkan pentingnya mengakomodasi kegiatan belajar di sekolah untuk individu autisme sesuai dengan stimulasi aktivitas yang dilakukan. Perancangan cahaya mempengaruhi kesan ruang dan dapat berdampak pada perilaku anak autisme berdasarkan penilaian dari staf pengajar di sekolah. Penelitian ini masih terbatas pada salah satu objek sekolah dan dapat dilanjutkan dengan mengkaji lebih banyak objek untuk mempelajari strategi pencahayaan untuk individu autisme yang lebih lengkap. Selain itu, dalam penelitian lanjutan juga dapat digunakan metode untuk menggali persepsi langsung dari individu autisme agar mendapatkan data persepsi yang lebih akurat.

\section{DAFTAR PUSTAKA}

Egan, D., \& Olgyay, V. (2001). Architectural Lighting. McGraw-Hill Science. Ginanjar, A.S. (2007). Memahami Spektrum Autistik Secara Holistik. Makara Sosial Humaniora, 11(2), hlm. 90-91. Available at: http://hubsasia.ui.ac.id/old/index.php/hu bsasia/article/view/121/90 [20 Agustus 2019]

Gunawan, G (2019). Pengaruh Sirip Penangkal Sinar Matahari Terhadap Pencahayaan
DOI: $\underline{\text { http://dx.doi.org/10.24912/jurnal.v17i1.17366 }}$

Alami Ruang Kelas BPK Penabur Summarecon Bekasi. Bandung: Universitas Katolik Parahyangan.

Janviere, J. (2009). Understanding Color. Available at: https://www.slideshare.net/JenniferJanvi ere/understanding-color1974960?from_action=save [diakses 10 November 2019]

Lechner, N. (2015). Heating, Cooling, Lighting: Sustainable Design Methods for Architects (4th ed). New Jersey: John Wiley \& Sons, Inc.

Long, E. A. (2010). Classroom Lighting Design for Students with Autism Spectrum Disorders.

Mandala, A., \& Sheila, V. (2018). Kontribusi Pencahayaan Buatan terhadap Kualitas Visual Bangunan pada Malam Hari. RUANG: Jurnal Lingkungan Binaan (SPACE: Journal Of The Built Environment), 5(1), 25-36.

Mirrahimi, S., Nik Ibrahim, N. dan Surat, M. (2013). Estimation Daylight to Find Simple Formulate Based on the Ratio of Window Area to Floor Area Rule of Thumb for Classroom in Malaysia. Malaysia: Research Journal of Applied Sciences, Engineering and Technology,6(5).

Mostafa, M (2008). An An Architecture for Autism: Concepts of Design Intervention 
Fakultas Seni Rupa dan Desain - Universitas Tarumanagara

for the Autistic User. Archnet-IJAR : International Journal of

Mustofa, M (2014). Architecture for Autism:

Autism ASPECTSS in School Design. International Journal of Architectural Research: ArchNET-IJAR, 8(1), hlm. 146148

Ru, T., de Kort, Y. A. W., Smolders, K. C. H. J., Chen, Q., \& Zhou, G. (2019). Non-image forming effects of illuminance and correlated color temperature of office light on alertness, mood, and performance across cognitive domains. Building and Environment, 149, 253-263.

Russell, J. (1980): A Circumplex Model of Affect, Journal of Personality and Social Psychology, 39, 1161-1178.

Septia. D, Mauliani. L \& Anisa. (2017). Pengaruh Perilaku Penyandang Autis Terhadap Desain Ruang Dalam. Studi Kasus: Bangunan Pendidikan. Jurnal Arsitektur Purwarupa, 1(2).

Smolders, K. C. H. J., \& de Kort, Y. A. W. (2014). Bright light and mental fatigue: Effects on alertness, vitality, performance and physiological arousal. Journal of Environmental Psychology, 39, 77-91.

Sutanto, E. B. H. (2017). Prinsip-prinsip Pencahayaan Buatan dalam Arsitektur. Daerah Istimewa Yogyakarta: PT Kanisius.
Yates, M. (2016). Building Better Schools: A New Model For Autism Inclusion in Seattle. University of Washington.

Vogels, I. (2008): Atmosphere Metrics: Development of a tool to quantify experienced atmosphere, 25-41 in J.M.D.M. Westerink, M. Ouwerkerk, T. J. . Overbeek, W. F. Pasveer, and B. de Ruyter, eds., Probing Experience, Springer, Dordrecht. 